\title{
PENGARUH EKSTRAK DAUN BABADOTAN (AGERATUM CONYZOIDES, L) TERHADAP WAKTU PEMBEKUAN DARAH
}

\section{Farhan Baehaki, Aziz Ansori Wahid, dan Dani Suparman}

\begin{abstract}
ABSTRAK
Latar Belakang: Luka merupakan rusak atau hilangnya jaringan tubuh. Jika terjadi luka disekitar pembuluh darah yang rusak, maka akan terjadi proses penghentian pendarahan dan perbaikan jaringan sebagai respon tubuh melalui proses hemostasis. Babadotan (Ageratum conyzoides, $L$ ) merupakan salah satu tanaman yang memiliki kandungan senyawa aktif untuk mempercepat proses hemostasis.

Tujuan Penelitian: Untuk mengetahui pengaruh pemberian ekstrak daun babadotan terhadap waktu pembekuan darah.

Metode Penelitian: Metode penelitian yang digunakan yaitu quasy experiment (eksperimen semu). Rancangan ini berupaya untuk mengungkapkan hubungan sebab akibat dengan cara melibatkan kelompok kontrol dan kelompok eksperimen. Data yang diperoleh merupakan data primer yaitu data yang didapatkan dari hasil pemeriksaan waktu pembekuan darah dengan pemberian dan tanpa pemberian ekstrak daun babadotan dengan metode pemeriksaan Lee and White.

Hasil: Rerata waktu pembekuan dari sampel darah yang tanpa perasan daun babadotan yaitu 9,89 menit, sedangkan sampel darah yang diberikan perasan daun babadotan menunjukkan waktu pembekuan 9,19 menit. Sehingga selisih waktu pembekuan pada kedua sampel adalah 0,7 menit atau lebih cepat sebesar $7 \%$.
\end{abstract}

Simpulan: Ekstrak daun babadotan (Ageratum lonyzoides,L) dapat digunakan untuk mempercepat waktu pembekuan darah.

Kata Kunci: Ageratum Conyzoides, $l$, Daun babadotan, Metode Lee and White, Waktu pembekuan darah

\section{PENDAHULUAN}

Perkembangan zaman yang sangat pesat turut menuntut kemajuan di bidang kesehatan, salah satunya adalah pengembangan terkait obat-obatan. Keberagaman masalah kesehatan yang terjadi pada tubuh menuntut adanya pengembangan obat-obatan secara terusmenerus. Keberagaman masalah kesehatan ini dapat ditimbulkan dari aktivitas yang dilakukan sehari-hari, seperti pola makan, pola kerja, dan sebagainya. Salah satu gangguan kesehatan tubuh yang sering terjadi dan paling banyak dijumpai adalah luka. Luka merupakan rusak atau hilangnya jaringan tubuh yang terjadi karena adanya faktor yang mengganggu sistem perlindungan tubuh, baik secara tertutup maupun terbuka (Pusponegoro, 2003). Luka terbuka atau luka luar memungkinkan untuk terputusnya jaringan kulit atau membrane mukosa sehingga disertai kerusakan jaringan, pendarahan, dan meningkatkan resiko infeksi. 
Ketika tubuh mengalami luka luar, tubuh akan memberikan respon melalui proses hemostatis (Nugraha, 2015). Pada proses tersebut terjadi penghentian darah (pembekuan darah) dan perbaikan jaringan. Proses pembekuan darah melibatkan proses dimana komponen cairan darah ditransformasikan menjadi material semisolid (bekuan darah) (Zaetun, 2014). Vasokontriksi pembuluh darah akan terjadi saat tubuh mengalami luka pada pembuluh darah sehingga aliran darah ke pembuluh darah yang terluka menjadi berkurang. Proses ini berlanjut dengan berkumpulnya trombosit dan melekat pada bagian pembuluh darah membentuk sumbatan trombosit. Faktor pembekuan darah akan teraktivasi dan membentuk benang fibrin yang menyebabkan sumbat trombosit menjadi non permeable melalui tahap adhesi trombosit, agregasi trombosit, dan reaksi pelepasan sehingga pendarahan dapat dihentikan (Setiabudy, 2012). Fibrin merupakan suatu protein yang bersifat tidak larut dan berbentuk seperti jaringjaring benang sehingga mampu menahan sel-sel darah pada saat proses pembekuan berlangsung (Zaetun, 2014).

Penggunaan obat-obat berbahan dasar zat sintetis sering memberikan efek samping terhadap tubuh (Butsanusalam, 2016). Selain itu, biaya yang diperlukan pun menjadi salah satu kendala lainnya. Oleh karena itu, pengembangan obat-obatan berbahan dasar alami atau herbal perlu dikembangkan. Obat herbal adalah bahan atau ramuan bahan berupa bahan tumbuhan, bahan hewan, bahan mineral, sediaan sarian (galenik) atau campuran dari bahan tersebutyang secara turun temurun telah digunakan untuk pengobatan, dan dapat diterapkan sesuai dengan norma yang berlaku di masyarakat (Peraturan Menteri Kesehatan Republik Indonesia, 2012). Obat-obatan jenis ini dapat meminimalisir efek samping, bahkan relatif mudah didapat dan lebih murah. Bahkan World Health Organization (WHO) merekomendasikan penggunaan obat herbal dalam pemeliharaan kesehatan masyarakat, pencegahan dan pengobatan peyakit, terutama untuk penyakit kronis, penyakit degeneratif dan kanker.

Salah satu tanaman herbal yang mampu mempercepat proses penghentian darah saat luka terjadi adalah babadotan (Ageratum conyzoides, L). Tanaman ini mengandung berbagai macam zat aktif, seperti asam amino, tanin, stigmasterol, friedelin, sulfur, potassium, klorida, pectic substance, agaretochromane, $\beta$-sitoserol, flavonoid dan polifenol (Dalimarta, 2000). Dari berbagai macam zat aktif tersebut, flavonoid merupakan zat aktif yang dapat berperan saat proses penghentian pendarahan akibat pecahnya pembuluh darah (Soegijanto, 2006; Zaetun, 2014; dan Putra, Dharmayudha, dan Sudimartini, 2016). Sedangkan zat aktif lainnya, 
yaitu tanin, mampu mengendapkan protein-protein darah sekaligus mengerutkan jaringan pada pendarahan yang sempit sehingga berguna sebagai hemostatik dan pembekuan darah (Apriyani, Sunarni, dan Ningsih, 2011).

Pemeriksaan yang dapat digunakan untuk mengukur waktu pembekuan darah salah satunya adalah Clotting Time. Cloting time adalah pemeriksaan untuk menentukan waktu yang dibutuhkan darah untuk membeku secara in-vitro, satuan yang digunakan dalam pemeriksaan waktu pembekuan adalah menit (Nugraha, 2015). Salah satu metode yang dapat digunakan pada pemeriksaan Clotting Time adalah Metode Lee and White (metode tabung). Darah lengkap tanpa antikoagulan di dalam tabung akan mengalami pembekuan darah akibat adanya kontak langsung dengan permukaan tabung. Metode tabung menggunakan 3 tabung masing-masing terisi $1 \mathrm{ml}$ darah yang ditempatkan pada waterbath suhu $37^{\circ} \mathrm{C}$, kemudian tabung perlahan-lahan dimiringkan pada sudut 40 derajat, setiap 30 detik supaya darah bersentuhan dengan dinding tabung sekaligus melihat sudah terjadinya pembekuan (Nugraha, 2015).

Penelitian tentang pengaruh penambahan perasan/ekstrasi tentang daun babadotan (Ageratum Conyzoides,L) telah banyak dilakukan. Apriani, Sunarni dan Ningsih (2011) melakukan penelitian tentang efek ekstrak etanol bandotan (angeratum conyzoides,l) terhadap waktu pendarahan dan pembekuan darah pada tikus putih jantan (ratus norvegicus). Penelitian tersebut menunjukkan penurunan waktu pendarahan dan pembekuan darah pada tikus putih jatan (Rattus Norvegicus) sebesar 85,45\% dan 70\% pada T3 (hari ke enam). Selain itu, Bamidele et.al., (2010) melakukan penelitian tentang efek hemostatik ekstrak daun metanol bandotan pada tikus albino dan mendapatkan hasil rerata waktu pembekuan menurun signifikan pada kelompok eksperimen dibandingkan dengan kelompok kontrol. Penelitian lebih lanjut perlu dilakukan, khususnya untuk proses pembekuan darah manusia sehingga dapat digunakan sebagai bahan dasar dalam pengembangan obat luar.

\section{METODE}

\section{Desain Penelitian}

Metode yang digunakan pada penelitian ini adalah quasy experiment, dimana metode ini bertujuan untuk mengungkapkan hubungan sebab akibat dengan melibatkan kelompok kontrol dan kelompok eksperimen (Nursalam, 2015). Langkah-langkah penelitian yang dilakukan dapat dilihat pada Gambar 1. 


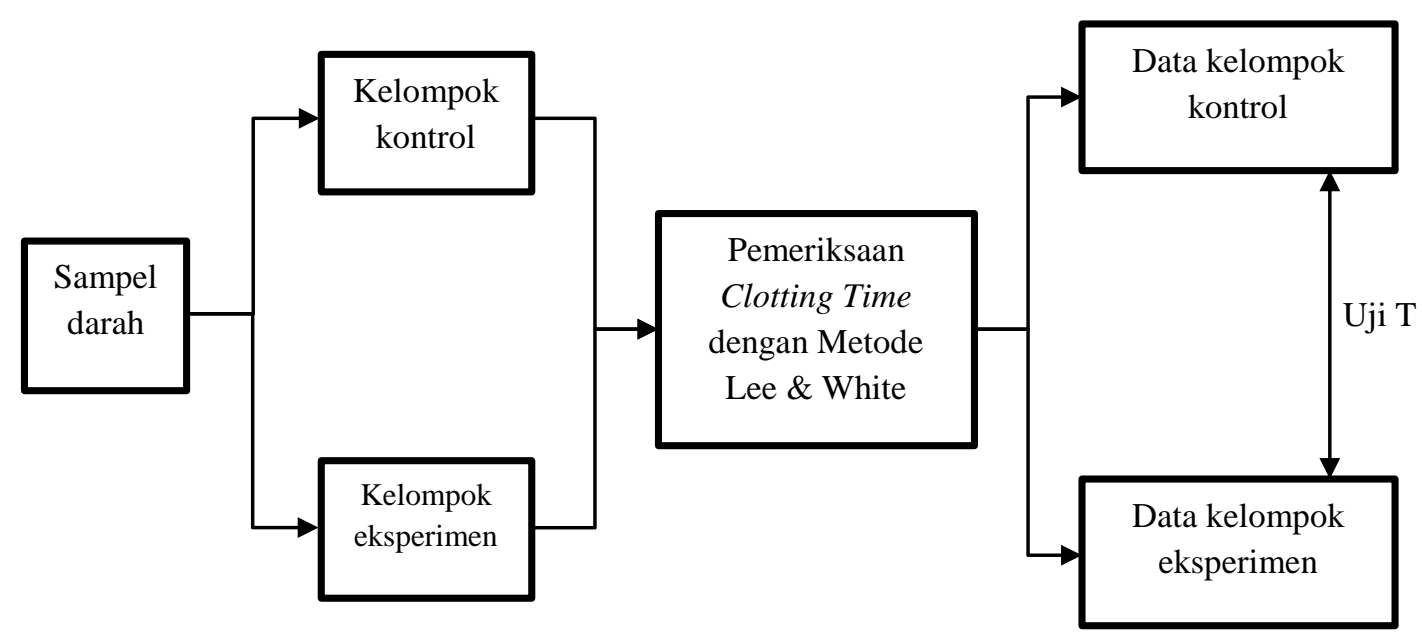

Gambar 1. Mekanisme Penelitian Pemeriksaan Clotting time

Variabel merupakan ukuran atau ciri yang dimiliki oleh suatu kelompok. Sifat atau ciri ini akan berbeda dengan yang dimiliki oleh kelompok lain. Beberapa variabel yang umum adalah variabel independen dan variabel dependen. Variabel independen atau variabel bebas adalah variabel yang mempengaruhi atau dianggap menentukan variabel dependen. Variabel ini dapat merupakan faktor risiko, prediktor, kausa/penyebab (Saryono, 2013). Variabel independen atau variable bebas di dalam penelitian ini adalah perlakuan pemberian ekstrak daun babadotan pada sampel. Sedangkan variabel dependen atau variabel terikat adalah variabel yang dipengaruhi oleh variabel independen. Variabel dependen disebut juga kejadian, luaran, manfaat, efek atau dampak (Saryono, 2013). Variable dependen pada penelitian ini adalah waktu pembekuan darah.

\section{Sampel dan Lokasi Penelitian}

Penelitian dilakukan di Laboratorium Hematologi, Sekolah Tinggi Ilmu Kesehatan Rajawali. Sedangkan sampel penelitian diperoleh dari mahasiswa Sekolah Tinggi Ilmu Kesehatan Rajawali sebanyak 30 orang. Sampel dipilih berdasarkan kriteria tertentu yang harus dipenuhi, yaitu mahasiswa yang sedang tidak mengkonsumsi obat dan memiliki penyakit yang mempengaruhi pembekuan darah. Hal ini dilakukan agar diperoleh kondisi darah dan proses pembekuan darah yang normal. Sehingga dapat menghindari hal-hal yang dapat mempengaruhi proses pengukuran waktu pembekuan darah.

\section{Pengambilan dan Teknik Analisis Data}

Sampel yang diperoleh diuji dengan pemeriksaan metode Clotting Time menggunakan Metode Lee and White. Gambar 1 menunjukkan bahwa sampel dibagi menjadi dua kelompok, yaitu kelompok kontrol dan kelompok eksperimen. Pada kelompok kontrol merupakan kelompok sampel dengan pengukuran waktu pembekuan darah dilakukan tanpa 
pemberian ekstrak daun babadotan. Sedangkan pada kelompok eksperiman yaitu kelompok sampel dengan pemberian ekstrak daun babadotan dilakukan sebelum proses pengukuran waktu pembekuan dilakukan. Untuk mengetahui adanya pengaruh secara siginfikan dari pemberian ekstrak daun babadotan terhadap waktu pembekuan darah, maka dilakukan uji statistik menggunakan Uji T.

Prosedur pengambilan data pada sampel dilakukan melalui tiga tahap, yaitu tahap praanalitik, analitik, dan pasca-analitik. Gambar 2 menunjukkan rangkaian kegiatan secara lengkap pada setiap tahap penelitian. Tahap pra-analitik merupakan langkah awal untuk memperoleh informasi dari partisipan tentang kondisinya pada saat akan dilakukan pengambilan darah sebagai sampel. Hal ini dilakukan untuk menghindari faktor-faktor yang dapat mempengaruhi hasil pengukuran. Sebelum melakukan pengambilan darah, partisipan juga diberikan lembar persetujuan untuk diambil darahnya sebagai sampel. Selain itu, pada tahap ini dilakukan pembuatan esktrak daun babadotan. Pembuatan larutan ini dilakukan dengan menghaluskan sebanyak 500 gram daun babadotan menggunakan mortil. Kemudian daun babadotan yang telah dihaluskan diperas menggunakkan kain kasa steril dan disaring menggunakan kertas saring. Filtrat yang diperoleh ditampung di dalam tabung Erlenmeyer.
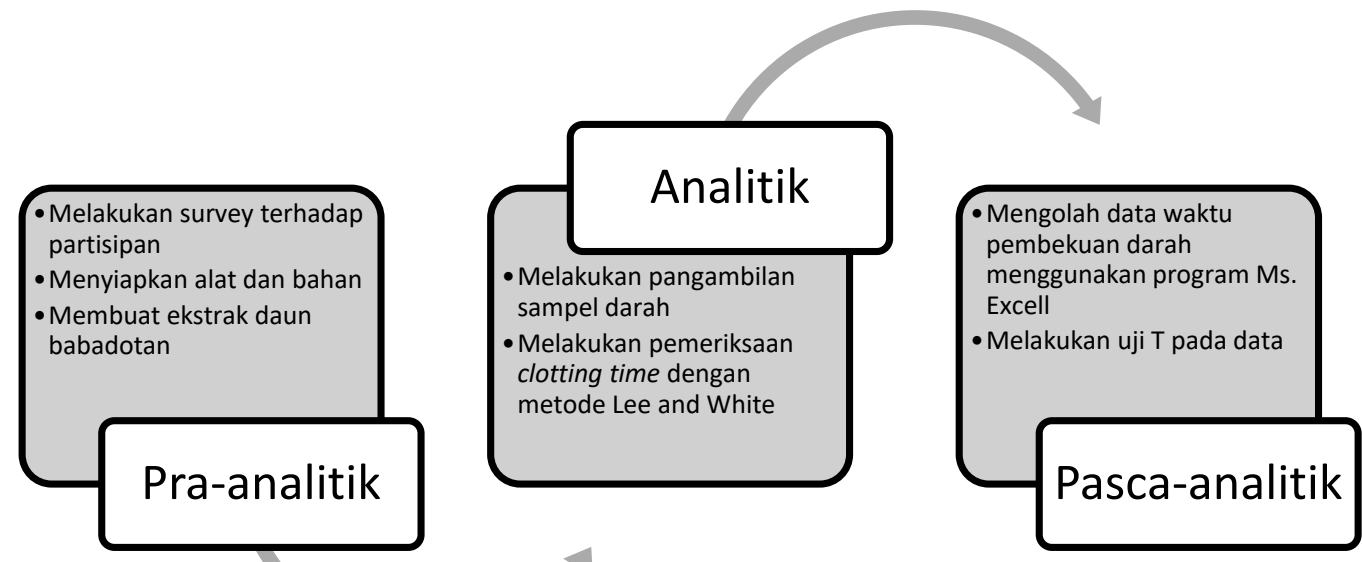

Gambar 2. Prosedur Penelitian Pemeriksaan Waktu Pembekuan Darah Dengan Ekstrak Daun Babadotan dan Tanpa Ekstrak Daun Babadotan

Tahap analitik merupakan tahap pemeriksaan clotting time. Pada tahap ini dilakukan pengambilan sampel darah. Darah yang diambil kemudian ditampung ke dalam enam buah tabung serologi yang telah dilabeli dengan angka 1 hingga 6. Tabung 1 sampai 3 merupakan sampel yang tidak diberi ekstrak daun babadotan, sedangkan tabung 4 sampai 6 merupakan 
tabung yang diberikan ekstrak daun babadotan. Jumlah ekstrak daun babadotan yang ditambahkan ke dalam tabung 4 sampai 6 adalah $100 \mu \mathrm{L}$. Pengukuran waktu dilakukan dengan stopwatch, dinyalakan saat darah masuk ke dalam indikator spuit.

Pada tahap pasca-analitik, data yang diperoleh disajikan dalam bentuk tabel pada program Ms. Excell. Data ini diolah dengan program tersebut untuk melihat perbedaan rerata waktu pembekuan darah pada kelompok kontrol dan kelompok eksperimen. Sedangkan untuk melihat pengaruh pemberian esktrak daun babadotan terhadap waktu pembekuan darah, dilakukan uji statistik menggunakan uji T pada program SPSS dengan tingkat kepercayaan $95 \%$.

\section{HASIL PENGAMATAN}

Pemeriksaan clotting time dengan metode Lee and White dilakukan kepada 30 partisipan yang telah memenuhi kriteria dan bersedia untuk dilakukan pengambilan darahnya. Artinya, seluruh sampel telah diidentifikasi dengan kondisi darah dalam keadaan normal. Pemenuhan kriteria ini karena adanya gangguan patologis dapat mempengaruhi proses pembekuan darah, bahkan kondisi sampel yang sedang mengkonsumsi obat-obatan seperti aspirin dan anti inflamasi juga dapat mengganggu proses pembekuan darah. Tabel 1 menunjukkan bahwa waktu pembekuan darah pada sampel kontrol (sampel tanpa pemberian ekstrak daun babadotan) rata-ratanya adalah 9,89 menit. Sedangkan waktu pembekuan darah pada sampel eksperimen (sampel yang diberi ekstrak daun babadotan) menunjukkan rata-rata waktu yaitu 9,19 menit. Data ini menunjukkan adanya perbedaan waktu sebesar 0,70 menit.

Tabel 1. Data Hasil Pemeriksaan Clotting Time Dengan Menggunakan Metode Lee and White

\begin{tabular}{lccccc}
\hline \multicolumn{1}{c}{ Sampel } & N & $\begin{array}{c}\text { Rerata } \\
\text { Waktu } \\
\text { Pembekuan }\end{array}$ & SB & $\begin{array}{c}\text { Waktu Pembekuan } \\
\text { Minimal } \\
\text { (menit) }\end{array}$ & $\begin{array}{c}\text { Waktu Pembekuan } \\
\text { Maksimal } \\
\text { (menit) }\end{array}$ \\
\hline $\begin{array}{l}\text { Kontrol (tanpa } \\
\text { ekstrak daun } \\
\text { babadotan) }\end{array}$ & 30 & 09.89 & 1,71 & 08.00 & 12.00 \\
\hline $\begin{array}{l}\text { Eskperimen } \\
\text { (ditambah ekstrak } \\
\text { daun babadotan) }\end{array}$ & 30 & 09.14 & 1,21 & 07.00 & 11.30 \\
\hline
\end{tabular}


Hal ini menunjukkan adanya pengaruh dari pemberian ekstrak daun babadotan jika dilihat menggunakan data deskriptif. Namun, untuk mengetahui signifikan atau tidaknya perbedaan waktu ini, maka perlu dilakukan uji secara statistikan, yaitu menggunakan Uji T. Data hasil analisis statistik menggunakan Uji T dapat dilihat pada Tabel 2. Nilai probabilitas (P) pada Tabel 2 menunjukkan angka 0.001 , artinya nilai tersebut berada di bawah nilai $\alpha$ yaitu 0.05

Tabel 2. Data Analisis Statistika Tentang Perbedaan Rerata Waktu Pembekuan Darah Dengan Menggunakan Uji T

\begin{tabular}{lccccc}
\hline & N & Rerarta+SB & Perbedaan+SB & IK 95\% & P \\
Tanpa Pemberian & 30 & $9,89 \pm 1,71$ & & & \\
$\begin{array}{l}\text { Ekstrak Daun } \\
\text { Babadotan }\end{array}$ & & & $0,70 \pm 0,41$ & $0,86 \pm 0,54$ & $<0,001$ \\
& & & & \\
$\begin{array}{l}\text { Dengan Pemberian } \\
\text { Ekstrak Daun }\end{array}$ & 30 & $9,19 \pm 1,21$ & & & \\
Babadotan & & & & & \\
\hline
\end{tabular}

atau dengan tingkat kepercayaan sebesar 95\%. Hasil ini menunjukkan bahwa pemberian ekstrak daun babadotan memberikan pengaruh yang signifikan terhadap waktu pembekuan darah.

\section{PEMBAHASAN}

Perbedaan waktu antara rerata waktu pembekuan darah yang diberikan ekstrak daun babadotan tanpa ekstrak daun babadotan dapat dilihat pada data di Tabel 1. Jika dilihat dari rentang waktunya, waktu pembekuan untuk sampel kontrol terjadi pada rentang 8 menit sampai dengan 12 menit. Sedangkan untuk sampel eksperimen terjadi pada rentang 7 menit sampai dengan 11 menit 30 detik. Adanya rentang waktu dalam satu kelompok sampel dapat dipengaruhi oleh adanya faktor teknis dan faktor klinis yang mungkin terjadi saat melakukan pemeriksaan. Dalam hal ini, faktor teknis yang dapat mempengaruhi keberagaman hasil pengukuran waktu pembekuan darah tersebut adalah proses pengambilan sampel darah (Zaetun, 2014). Proses pengambilan sampel darah harus dilakukan dengan tepat karena akan mempengaruhi waktu pembekuan. Jika jeda waktu terlalu lama saat pengambilan sampel dengan pengukuran waktu pembekuan, maka lama pembekuan akan memiliki nilai yang kecil atau lebih cepat dari seharusnya karena proses pembekuan mulai berlangsung saat darah keluar dari tubuh. Akan tetapi, jika proses pengambilan terlalu cepat dapat mengakibatkan 
terjadinya lisis. Terjadinya lisis dapat mempengaruhi proses pembekuan darah karena pecahnya eritrosit. Sedangkan faktor klinis meliputi kelainan dalam darah, jumlah trombosit, hemophilia, dan sebagainya yang dapat mempengaruhi waktu proses pembekuan darah.

Berdasarkan selisih rata-rata waktu pembekuan darah, sampel ekperimen lebih cepat 0,7 menit (7\%) daripada sampel kontrol. Untuk mempertegas perbedaan waktu pembekuan darah ini dipengaruhi oleh adanya penambahan ekstrak daun babadotan, maka perlu dilakukan uji statistika menggunakan uji T. Tabel 2 menunjukkan hasil analisis dari uji T dimana $\mathrm{P}$ value bernilai <0,01. Nilai ini menunjukkan bahwa kedua nilai rata-rata sampel berbeda secara signifikan. Berdasarkan data tersebut, maka dapat dikatakan bahwa pemberian ekstrak daun babadotan dapat mempercepat waktu pembekuan darah secara signifikan. Penurunan waktu pembekuan ini disebabkan adanya kandungan senyawa-senyawa aktif di dalam tanaman babadotan, beberapa diantaranya adalah tanin dan flavonoid (Rosmiati dan Vincent, 1995; Dalimarta, 2000). Keberadaan tanin mampu mengendapkan protein darah dan mengerutkan jaringan pembuluh darah sempit. Tanin dapat berperan sebagai astrigen yang menyebabkan penutupan pori-pori kulit, memperkeras kulit, menghentikan eksudat dan pendarahan yang ringan (Anief, 1997). Sedangkan flavonoid dapat berperan sebagai anti inflamasi yang dapat mengurangi peradangan dan rasa nyeri (Liana dan Utama, 2018). Selain itu, flavonoid juga berperan pada proses pembekuan darah dengan mempercepat keluarnya trombosit. Sementara keberadaan trombosit di dalam darah merupakan salah satu faktor pembekuan darah. Trombosit yang terkumpul akan segera membentuk sumbatan trombosit yang bersifat nonpermeabel dengan mengubah fibrinogen menjadi benang fibrin yang dibentuk oleh faktor pembekuan darah (Setiabudy, 2012; Zaetun, 2014; Apriyani, Sunarni, dan Ningsih, 2011; Soegijanto, 2006; dan Durahim dan Astuti, 2018).

Ditinjau dari manfaatnya sebagai tanaman obat luka luar, ekstrak daun babadotan juga harus memiliki kemampuan sebagai anti-bakteri. Bukan hal yang tidak mungkin jika mikroorganisme dapat masuk ke dalam tubuh melalui luka. Ketika luka terjadi, resiko terjadinya infeksi akibat masuknya mikroorganisme menjadi sangat tinggi. Adanya senyawa tanin dan flavonoid di dalam ekstrak daun babadotan juga dapat berperan untuk merusak membran sel mikroorganisme melalui proses penghambatan metabolisme energi dan pembentukan senyawa kompleks dengan protein ekstraseluler dan terlarut (Cowan, 1999; Nuria et al., 2009; Bobbarala, 2012; dan Cushnie and Lamb, 2005). Selain itu, adanya senyawa polifenol sebagai salah satu senyawa alkohol pada umumnya juga dapat berfungsi untuk menghambat aktivitas bakteri. Mekanisme kerja tanin untuk menghambat aktivitas bakteri yaitu dengan menghambat 
enzim reverse transkriptase dan DNA topoisomerase sehingga sel bakteri tidak dapat terbentuk (Nuria et al., 2009). Selain itu, tanin juga mampu menghambat proses transport protein di dalam sel yang dapat berperan dan proses metabolisme dan menghambat pembentukan dinding sel sehingga sel bakteri menjadi lisis dan mati (Cowan, 1994 dan Sari dan Sari, 2011). Sedangkan mekanisme kerja flavonoid yaitu dengan membentuk senyawa kompleks dengan senyawa protein ekstraseluler dan terlarut sehingga dapat merusak membran sel bakteri dan diikuti dengan keluarnya senyawa intraseluler, bahkan dengan terbentuknya basa nukleat dari flavonoid dapat menghambat proses metabolisme energi (Cowan, 1999; Nuria et al, 2009; Bobbarala, 2012; dan Ngajow, Abidjulu, dan Kamu, 2013).

\section{SIMPULAN}

Daun babadotan merupakan tanaman obat yang dapat digunakan untuk mengobati luka. Keberadaan senyawa aktif tanin dan flavonoid yang terkandung di dalam tanaman ini dapat mempercepat terjadi proses pembekuan darah. Selain itu, senyawa flavonoid dan polifenol juga dapat berperan aktif sebagai anti-bakteri sehingga dapat mengurangi resiko terjadinya infeksi akibat masuknya mikrorganisme ke dalam luka. Dengan demikian, melalui proses pengolahan yang tepat, tanaman ini dapat dijadikan sebagai bahan dasar dalam pembuatan obat luka luar yang efektif dan efisien.

\section{SARAN}

Penelitian yang dilakukan masih dibatasi hanya untuk mengukur perbedaan waktu pembekuan darah. Pengkajian lebih lanjut perlu dilakukan tentang manfaat dari ekstrak daun babadotan terhadap proses pembekuan darah, yaitu:

1. Efek samping secara klinis mungkin dapat ditimbulkan sehingga perlu dilakukan penelitian lebih lanjut yang berkaitan tentang hal tersebut.

2. Perlu dilakukan juga penelitian lebih lanjut tentang berapa kadar senyawa aktif yang berperan dalam proses pembekuan darah (flavonoid dan tanin), khususnya pada setiap bagian tumbuhan, seperti daun, batang, dan akar.

3. Aktivitas antibakteri juga perlu dilakukan untuk mengukur tingkat efektifitas antibakteri ekstrak tumbuhan ini sehingga dapat memperkuat informasi dalam hal pencegahan terjadinya infeksi pada luka. 


\section{DAFTAR PUSTAKA}

Anief, M. 1997. Formulasi Obat Tropikal Dengan Dasar Penyakit Kulit. Yogyakarta: Gadjah Mada University Press.

Apriyani, S., Sunarni, T., Ningsih, D. 2011. Efek Ekstrak Ethanol Herba Babadotan (Ageratum conyzoides, L) Terhadap Waktu Pendarahan dan Pembekuan Darah Pada Tikus Putih Jantan (Rattus norvegicus). Jurnal Farmasi Indonesia. 8(1): 77 -84 .

Bamidel, O., Akinnuga, A. M., Anyakudo, M. M. C. 2010. Efek Hemostatik Ekstrak Daun Methanol Babadotan pada Tikus Albino. Journal of Medical Plats. 4(20): 2075 2079.

Bobbarala, V. 2012. Antimicrobial Agents. Intech, Croatia.

Butsanusalam. 2016. Pemanfaatan Obat Tradisional (Herbal) Sebagai Obat Alternatif. Biotrend, 7(1).

Cowan, M.M. 1999. Plant Products as Antimicrobial Agents. Clinical Microbiology Reviews. 12: $564-582$.

Cushnie, T.P.T., dan A.J. Lamb. 2005. Antimicrobial Activity of Flavonoids. International Journal of Antimicrobial Agents. 26: 343 - 356.

Dalimartha, S. 2000. Atlas Tumbuhan Obat 2th Ed. Jakarta : Trubus Agriwidya.

Durahim, A. dan Astuti, D. 2018. Hemostatis (Bahan Ajar Teknologi Laboratorium Medik. Jakarta : Kementerian Kesehatan Republik Indonesia.

Hassanpour, S., Maheri, N., Eshratkhah, B., dan Mehmandar, F. B. 2013. Tanaman dan Metabolit Skunder (Tanin). International Journal of Forest. 1(1): 47-53.

Indisari, D. 2009. 100\% Sembuh Tanpa Dokter A-Z Deteksi, Obati dan Cegah Penyakit. Yogyakarta : Pustaka Grhatama.

Liana, Y. dan Utama, Y. A. 2018. Efektifitas pemberian ekstrak daun betadine (jatropha muitifida linn) terhadap ketebalan jaringan granulasi dan jarak tepi luka pada penyembuhan luka sayat tikus putih (rattus norvegicus). JKK. 5(3), 114-123. 
Ngajow, M., Abidjulu, J., dan Kamu, V. S. Pengaruh Antibakteri Ekstrak Kulit Batang Matoa (Pometia pinnata) terhadap Bakteri Staphylococcus aureus secara In vitro. Jurnal MIPA UNSRAT. 2(2), 128 - 132.

Nugraha, G. 2015. Panduan Pemeriksaan Labolatorium Hematologi Dasar. Jakarta: CV Trans Info Media.

Nuria, M.C., A. Faizatun., dan Sumantri. 2009. Uji Antibakteri Ekstrak Etanol Daun Jarak Pagar ( Jatropha cuircas L) terhadap Bakteri Staphylococcus aureus ATCC 25923, Escherichia coli ATCC 25922, dan Salmonella typhi ATCC 1408. Jurnal Ilmu - ilmu Pertanian. 5: 26 - 37.

Nursalam. 2015. Metodologi Penelitian Ilmu Keperawatan 4th ed. Jakarta Selatan: Salemba Medika.

Pusponegoro, Ahmadsyah, I., Prasetyo, T. O., \& A. D. 2003. Luka, Buku Ajar Ilmu Bedah. Jakarta: EGC.

Putra, I. W. D. P., Dharmayudha, A. A. G. O., dan Sudimartini, L. M. 2016. Identifikasi Senyawa Kimia Ekstrak Etanol Daun Kelor (Moringa oleifera L) di Bali. Indonesia Medicus Veterinus. 5(5), $464-473$.

Saryono, Anggrraeni, M. D. 2013. Metodologi Penelitian Kualitatif Dan Kuaantitatif Dalam Bidang Kesehatan. Yogyakarta: Nuha Medika.

Setiabudy, R. D. 2012. Hesmostasis dan Trombosis 5th ed. Jakarta: FKUI.

Zaetun, S. 2014. Daya Hambat Getah Tanaman Jarak Tintir (Jatropha multifida linn) Terhadap Proses Penyembuhan Luka Ditinjau Dari Hasil Pemeriksaan Cloting Time. Jurnal Kesehatan, 8(2). 